\title{
STUDY CONCERNING THE CORROSIVE ACTIVITY PROPERTIES OF MONATOMIC ALCOHOL-GASOLINE BLENDS
}

\author{
Valerian Cerempei \\ Institute of Agricultural Technics Mecagro, M. Costin str. , 7, Chisinau, MD 2068 R. Moldova \\ Email: icmea_mecagro@yahoo.com
}

\begin{abstract}
The article studies the corrosive activity of the monatomic alcohol (ethanol, butanol) - gasoline mixtures on the materials from which the internal combustion engines are made. The corrosive influence of these blends was determined in dependence of their composition. It was established that the addition of butanol and triethylamine in the ethanol-gasoline mixture essentially reduces the corrosive activity of this mixture.
\end{abstract}

Keywords: mixture, butanol, ethanol, corrosion, gasoline, resistance, triethylamine.

\section{Introduction}

Based on previous researches [1,2,3] and monographs [4], was determined the corrosive activity of monatomic alcohols and their mixtures with gasoline on certain materials used in internal combustion engines (ICE) construction. However, the existing sources lack specific data concerning the degree of corrosive influence of the specified fuels on different materials, as well as argumentation of inhibitors which significantly reduce the corrosive activity of several substances in fuels compositions.

Consequently, the purpose of our research is to determine the degree of corrosive influence of monatomic alcohols and their blends with gasoline on the materials used in ICE's construction and to argue the substances, which effectively slow down the corrosive activity of these alcohols.

\section{Methodology of the experimental researches}

For our researches we used ethanol $\mathrm{C}_{2} \mathrm{H}_{5} \mathrm{OH}$ (volume fraction of absolute alcohol - 97.5\%), butanol $\mathrm{C}_{4} \mathrm{H}_{9} \mathrm{OH}$

$\mathrm{C}_{4} \mathrm{H}_{9} \mathrm{OH}$ (absolute alcohol - 99.9\% vol.), regular gasoline - 80 (low octane, COR 80), and the following blends: E20 ( $20 \%$ vol. ethanol, $80 \%$ vol. gasoline), B20 (20\% vol. butanol, $80 \%$ vol. gasoline), E16B16 (16\% vol. ethanol, 16\% vol. butanol, $68 \%$ vol. gasoline). We used two types of ethanol: food grade and the ester-aldehydic fraction.

The quality of fuels was assessed according to the determination of acids and alkali soluble in water; organic acids; sulfur; water. The acids and alkali soluble in water were determined as described in the standard procedures of GOST 6307. The concentration of organic acids was assessed according to the neutralization index (GOST 5985), which reflects the quantity in mg of potassium hydroxide, necessary to neutralize the organic acids in $100 \mathrm{~mL}$ of fuel. Sulfur content (mg/kg of fuel) was determined according to GOST 19121 - 73, and the presence of water and impurities according to GOST 2084. The corrosive activity of sulfur compounds was tested on the copper blade (GOST 6321).

The corrosive activity of the mentioned fuels was studied in practice, applying them to the materials, which contact with fuels in internal combustion engines: stee 110, copper, brass, aluminum, membrane polymer from the fuel pump, zinc alloy from the carburetor. Samples of materials for the study of corrosive resistance were prepared from the motor pieces of VAZ and ZMZ type.

Various methods are used to determine the corrosive resistance of materials: gravimetric, resistometric, radiochemical etc. [5,6]. Materials resistance to corrosion was assessed by using microscopes EDNET AG Digital (Germany) and Optical XS - 80 (Guangzhou (Sinosource, China), according to the decimal system. The scale of evaluation of the level of corrosive resistance of materials (table 1) was elaborated according to the recommendations $[5,6]$ and GOST $9.908-85$. The highest grade (10) was given to the materials, which had no change of the surface state after being kept in the mentioned fluid. The grades have been reduced depending on the share of specific areas showing a pronounced corrosive activity. The periodicity of corrosive resistance evaluation was about a month. 
The scale of assessment of the corrosive resistance level of materials in biofuels

\begin{tabular}{|c|c|c|c|c|c|c|c|}
\hline \multirow[b]{2}{*}{$\begin{array}{l}\text { Group of } \\
\text { resistance of } \\
\text { materials }\end{array}$} & \multicolumn{2}{|c|}{ Level (note) of: } & \multirow[b]{2}{*}{$\begin{array}{c}\text { Lost of } \\
\text { shine, \% }\end{array}$} & \multicolumn{2}{|c|}{ Points and pits of corrosion } & \multirow[b]{2}{*}{$\begin{array}{l}\text { Continuous } \\
\text { surface } \\
\text { corrosion, } \%\end{array}$} & \multirow{2}{*}{$\begin{array}{l}\text { Depth of de- } \\
\text { structured } \\
\text { layer of the } \\
\text { membrane } \\
\text { polymer, mm }\end{array}$} \\
\hline & $\begin{array}{l}\text { corrosive } \\
\text { resistance of } \\
\text { materials }\end{array}$ & $\begin{array}{c}\text { corrosive action } \\
\text { of fuels }\end{array}$ & & $\begin{array}{c}\text { corroded } \\
\text { surface, } \%\end{array}$ & $\begin{array}{c}\text { depth, mm/ } \\
\text { an }\end{array}$ & & \\
\hline \multirow[b]{2}{*}{ High resistance } & 10 & 0 & $<5$ & $<0.5$ & $<0.001$ & & \multirow{2}{*}{$\begin{array}{l}\text { Lack of } \\
\text { significant } \\
\text { changes }\end{array}$} \\
\hline & 9 & 1 & $<10$ & $0.5-1.0$ & $0.001-0.005$ & & \\
\hline \multirow{2}{*}{$\begin{array}{l}\text { Sufficient } \\
\text { resistance }\end{array}$} & 8 & 2 & $<20$ & $1.0-2.0$ & $0.005-0.010$ & & \\
\hline & 7 & 3 & $<50$ & $2.0-5.0$ & $0.010-0.050$ & & \\
\hline \multirow{2}{*}{$\begin{array}{l}\text { Reduced } \\
\text { resistance }\end{array}$} & 6 & 4 & $>50$ & $5.0-10$ & $0.050-0.1$ & $<5$ & $<0,5$ \\
\hline & 5 & 5 & & $10-20$ & $0.1-0.5$ & $5-10$ & $<1,0$ \\
\hline \multirow{3}{*}{ Low resistance } & 4 & 6 & & $20-50$ & $0.5-1.0$ & $10-20$ & \\
\hline & 3 & 7 & & $>50$ & $1.0-5.0$ & $20-50$ & \\
\hline & 2 & 8 & & & $5.0-10$ & $>50$ & \\
\hline Non-resistance & 1 & 9 & & & $>10$ & & $>1,0$ \\
\hline
\end{tabular}

\section{Results and discussions}

At the first stage of the research were estimated fuel properties that influence the corrosive activity.

In order to make analysis of the corrosive activity of fuels, their composition was initially studied. Chemical purity butanol and food grade ethanol, used in experiments contain the lowest amounts of impurities, and their composition meets the requirements of the respective standards, as well as the composition of technical ethanol (table 2).

Table 2

Composition of monoatomic alcohols used for the preparation of fuel ${ }^{1 *}$ measurements

\begin{tabular}{|c|c|c|c|c|c|}
\hline \multirow{3}{*}{ Component } & \multirow{3}{*}{ Butanol } & \multicolumn{4}{|c|}{ Ethanol } \\
\hline & & \multirow{2}{*}{$\begin{array}{c}\text { Food grade } \\
\text { (GOST } \\
\text { P51723-2001) }\end{array}$} & \multirow[b]{2}{*}{$\begin{array}{c}\text { Technical (GOST } \\
18300-87)\end{array}$} & \multicolumn{2}{|c|}{ EAF fraction } \\
\hline & & & & $\begin{array}{c}\text { from sweet } \\
\text { sorghum }\end{array}$ & $\begin{array}{c}\text { from cereals, } \\
\text { grapes }\end{array}$ \\
\hline Absolute alcohol, \% vol. & 99.7 & $95.0 \pm 0.2$ & 96.2 & $92-92.6$ & $93-94$ \\
\hline $\begin{aligned} \text { Mass concentration, } \mathrm{mg} / \mathrm{dm}^{3} & \\
\text { - } & \text { aldehydes } \\
\text { - } & \text { fusel oil } \\
\text { - } & \text { volatile acids } \\
\text { - } & \text { esters }\end{aligned}$ & 16 & $\begin{array}{l}4.0 \\
8.0 \\
15\end{array}$ & $\begin{array}{c}4.0-10.0 \\
4.0-10.0 \\
10.0-20.0 \\
25.0-40.0\end{array}$ & $\begin{array}{c}155-324 \\
40-400 \\
140 \\
70-180\end{array}$ & $\begin{array}{c}200-1600 \\
1200-1500 \\
142-190 \\
760-1200\end{array}$ \\
\hline Methylic alcohol, \% vol. & & 0.05 & - & 0.02 & $1.0-1.4$ \\
\hline Dry residue, $\mathrm{mg} / \mathrm{dm}^{3}$ & & & $2-15$ & $17-80$ & $22-180$ \\
\hline Oxidation test, minute & & & $15-10$ & 20 & 25 \\
\hline
\end{tabular}

The estero-aldehyde fraction (EAF) of ethanol, obtained from different raw material contains large amounts (mg/dm ${ }^{3}$ absolute alcohol) of aldehydes (up to 1600), esters (up to 1200), volatile acids (up to 190), fusel oil (up at 1500). Of these substances, only fusel oil practically does not react with the studied metals, and the remaining substances react to form oxides $\left(\mathrm{Cu}_{2} \mathrm{O}, \mathrm{CuO}\right)$, hydroxides $\left[\mathrm{Fe}(\mathrm{OH})_{3}, \mathrm{Al}_{2}(\mathrm{OH})_{3}\right]$ and other products.

The dry residue reflects primarily the amount of mechanical impurities which don't affect the corrosive activity of the fuel.

\footnotetext{
* The measurements were performed in the laboratory Verification of alcoholic beverages quality of INVV (Accreditation certificate SNC MD CNOO 41007)
} 
It is known $[2,10]$ that dehydrated alcohols, including ethanol, butanol, don't interact with metals and investigated alloys $(\mathrm{Cu}, \mathrm{Al}, \mathrm{Fe}, \mathrm{Zn})$. The presence in alcohols of aldehydes, esters and acids makes possible the chemical corrosive action of fuels on the metals. And the presence of water significantly increases the electrical conductivity of alcohols, allowing electrochemical corrosion.

The study of monoatomic alcohols composition allows forecasting the highest degree of corrosive activity in the estero-aldehyde fraction of ethanol due to increased concentration of aldehydes, esters, acids. Also the presence of water in alcohol stimulates their interaction with metals. Therefore, the actual degree of corrosive activity can be determined from experiments.

According to $[2,4,7,10,11] \mathrm{C}_{\mathrm{n}} \mathrm{H}_{\mathrm{m}}$ hydrocarbons from gasoline and dehydrated alcohols, don't interact with ICE materials. But gasoline contaminants (acids, alkali hydroxides, sulfur and sulfur compounds, water) interact with metals. Therefore, was verified the quality of petrol and mixtures monoatomic alcohol - gasoline (table 3).

Table 3

Exploitation properties of fuels

\begin{tabular}{|c|c|c|c|c|}
\hline \multirow[b]{2}{*}{ Fuel } & \multicolumn{4}{|c|}{ Corrosive properties } \\
\hline & $\begin{array}{l}\text { Neutralization index, } \\
\text { mgKOH/100 } \mathrm{cm}^{3}\end{array}$ & $\begin{array}{c}\text { Sulfur content, } \\
\mathrm{mg} / \mathrm{kg}\end{array}$ & $\begin{array}{c}\text { Copper blade } \\
\text { test }\end{array}$ & $\begin{array}{c}\text { Presence of } \\
\text { water, mechanical } \\
\text { impurities }\end{array}$ \\
\hline $\begin{array}{l}\text { Gasoline: } \\
\text { - normative SM226 } \\
\text { - real }\end{array}$ & $\begin{array}{c}<3 \\
0.12-0.53\end{array}$ & $\begin{array}{c}<1000 \\
250\end{array}$ & $\begin{array}{l}\text { resists } \\
\text { resists }\end{array}$ & $\begin{array}{l}\text { none } \\
\text { none }\end{array}$ \\
\hline Butanol & 0.56 & none & resists & none \\
\hline \multirow[t]{2}{*}{$\begin{array}{l}\text { Ethanol: } \\
\text { - EAF } \\
\text { - Food grade }\end{array}$} & & $\begin{array}{l}\text { none } \\
\text { none }\end{array}$ & & \\
\hline & \multicolumn{4}{|c|}{ Dual mixtures: } \\
\hline \multirow[t]{2}{*}{$\begin{array}{l}\text { - } \mathrm{B} 10 \\
\text { - } \mathrm{B} 20 \\
\text { - } \mathrm{E} 10(\mathrm{EAF}) \\
\text { - } \mathrm{E} 20(\mathrm{EAF}) \\
\text { - } \mathrm{E} 20 \text { (food grade) }\end{array}$} & $\begin{array}{c}0.14 \\
0.16 \\
0.14-0.96 \\
0.18-2.45 \\
0.20\end{array}$ & $\begin{array}{l}183 \\
164 \\
158\end{array}$ & $\begin{array}{l}\text { resists } \\
\text { resists } \\
\text { resists } \\
\text { resists } \\
\text { resists }\end{array}$ & $\begin{array}{l}\text { none } \\
\text { none } \\
\text { none } \\
\text { none } \\
\text { none }\end{array}$ \\
\hline & \multicolumn{4}{|c|}{ Triple mixture: } \\
\hline - E16B16 & 0.2 & 102 & resists & none \\
\hline
\end{tabular}

Acids and alkalis soluble in water generally interact with metals, so these substances are not allowed in gasoline. Tests of all gasoline samples used in the experiments revealed no water-soluble acids and alkalis. Organic acids interact with metals much weaker than water-soluble acids. Therefore, according to the standards, a limited presence of organic acids norms fuel is allowed. The limit is stipulated by the neutralization index, which reflects the amount of potassium hydroxide needed to neutralize the organic acids, which are contained in $100 \mathrm{~cm}^{3}$ of fuel. Sufficient corrosive resistance, according to MS 226 is provided, if the neutralization index does not exceed $3 \mathrm{mg} \mathrm{KOH} / 100 \mathrm{~cm}^{3}$.

In our studies the values of neutralization indices varied, for gasoline, between $0.12-0.53 \mathrm{mg} \mathrm{KOH} / 100 \mathrm{~cm}^{3}$, for the bio-gasoline E20 (with the estero-aldehyde fraction) - 0.18 - 2.45 and for the mixtures B20, E20 (food grade alcohol), E16B16 (food.) - 0.16-0.20 mg KOH/100 $\mathrm{cm}^{3}$. The increase of the volume concentration of ethanol (EAF) up to $40 \%$ (E40) led to the increase of the neutralization index up to $3.21 \mathrm{mg} \mathrm{KOH} / 100 \mathrm{~cm}^{3}$.

The results (table 2,3) demonstrate that the organic acids in alcohols can cause an increased corrosive action of fuel on metals. As to the case of long-term preservation, aldehydes and esters can be transformed in the presence of oxygen in organic acids, which increase the corrosive action.

Sulfur and its compounds, but in particular, their combustion products are the cause drive corrosive materials in contact with. Sulfur content in gasoline $(250 \mathrm{mg} / \mathrm{kg})$ does not exceed the norm $(1000 \mathrm{mg} / \mathrm{kg})$, and adding alcohol to the gasoline substantially reduces the sulfur content (up to $102 \mathrm{mg} / \mathrm{kg}$ ). Researches [4] show that adding alcohol to gasoline proportionally decreases the sulfur content in the fuel mixture. This happens due to the lack of visible quantities of sulfur 
and its compounds in the studied alcohols. Testing on the copper blade confirms the lack of essential quantities of active sulfur compounds, which promotes corrosive resistance of materials.

The qualitative method used in the study didn't allow detecting the presence of water or mechanical impurities in fuel composition (table 3).

The study of monoatomic alcohols composition (table 2) and corrosive properties of gasoline and of mixtures monoatomic alcohol - gasoline (table 3) allows only forecasting the behavior of materials in long contact with the specified fuels. To assess more accurately the long-term corrosive resistance of materials in biofuels, the next cycle of experiments was conducted.

Study of corrosion properties (table 4) of different materials in regular gasoline - 80, accomplished over a period of 36 months ( 3 years) showed that the membrane polymer of the fuel pump, aluminum, zinc alloy from the carburetor and steel containing a low-level of carbon have a sufficient corrosion resistance level. After long tests both the polymer and aluminum have suffered practically no change (fig. 1).

On the surface of zinc alloy a thin brown pellicle has formed, and on the steel surface corrosion spots appeared. More pronounced corrosion traces can be observed on the surfaces of copper and copper alloy with zinc.

In ethanol (ether-aldehyde fraction), only the polymer suffered practically no changes (tab. 4, fig. 2), brass surface covered with a thin dark green layer which has good adhesion with the base material. The situation is similar in the case of the zinc alloy. Other materials (aluminum, copper, steel) have insufficient corrosion resistance, which causes damage to their surfaces. The duration of obtaining an acceptable degree of corrosion in ethanol EAF is the lowest for steel ( 0.5 months), while for aluminum and copper it is equal to 1 month and 3 months, respectively.

Table 4

Long term anti-corrosive properties of materials in fuels with gasoline and monoatomic alcohols (ethanol, butanol)

\begin{tabular}{|c|c|c|c|c|c|c|c|}
\hline \multirow{2}{*}{ Fuel } & \multicolumn{7}{|c|}{$\begin{array}{l}\text { Integral indices of corrosive resistance of materials (note)/duration of obtaining } \\
\text { of admissible corrosion level (months) }\end{array}$} \\
\hline & Zn (alloy) & Al & $\mathrm{Cu}$ & Brass & Steel & $\begin{array}{l}\text { Membrane } \\
\text { polymer }\end{array}$ & $\begin{array}{l}\text { Duration, } \\
\text { months }\end{array}$ \\
\hline $\begin{array}{l}\text { Gasoline } \\
\text { Normal }-80\end{array}$ & 8 & 9 & 7 & 7 & 8 & 10 & 36 \\
\hline $\begin{array}{l}\text { Ethanol: } \\
\text { - EAF } \\
\text { - Food grade }\end{array}$ & $\begin{array}{l}7 \\
7\end{array}$ & $\begin{array}{c}2 / 1 \\
9\end{array}$ & $\begin{array}{c}4 / 3 \\
-\end{array}$ & $\begin{array}{c}7 \\
10\end{array}$ & $\begin{array}{c}2 / 0.5 \\
10\end{array}$ & $\begin{array}{l}9 \\
-\end{array}$ & $\begin{array}{l}36 \\
12\end{array}$ \\
\hline Butanol & 9 & 7 & 10 & 10 & 8 & - & 12 \\
\hline \multicolumn{8}{|l|}{ Dual mixtures: } \\
\hline - E20 (EAF) & $4 / 1.5$ & $4 / 3$ & $5 / 6$ & 8 & $2 / 0.5$ & 5 & 36 \\
\hline - E20+triethylamine & 9 & 7 & 10 & 10 & 10 & 10 & 36 \\
\hline - $\quad$ E20+pyridine & $5 / 2$ & $5 / 3$ & $6 / 8$ & $6 / 6$ & $1 / 0.3$ & 6 & 36 \\
\hline - $\quad$ E20+quinoline & $4 / 1.5$ & $6 / 4$ & $2 / 1.5$ & $2 / 1$ & $6 / 3$ & 1 & 36 \\
\hline - $\mathrm{B} 20$ & 10 & 10 & 8 & 10 & 10 & - & 12 \\
\hline - $\mathrm{B} 20+\mathrm{H}_{2} \mathrm{O}$ & 9 & 9 & 8 & 10 & 9 & - & 8 \\
\hline \multicolumn{8}{|l|}{ Triple mixtures } \\
\hline - $\quad$ E16B16 & 8 & 8 & 8 & 10 & 8 & - & 12 \\
\hline
\end{tabular}

In the food grade ethanol (fig. 3), and butanol (fig. 4) all materials showed a high degree of corrosive resistance, which is equal to or higher than for gasoline. The minimal degree of corrosive action of alcohols is due, primarily, to low concentrations of aldehydes, esters, acids (table 2, 3), while the ethanol concentration in water, in EAF and food grade ethanol in the experiments was approximately equal (2-4\% vol). Therefore, in the experimental conditions in the studies on corrosive activity of alcohols the influence of aldehydes, esters, acids is prevailing.

In the blend ethanol- gasoline E20, only the brass showed a sufficient level of resistance (fig. 5) having on the surface corroded points. In comparison with gasoline and ethanol, the blend E20 has higher corrosive activity for the zinc alloy and polymer (tab. 4), on the surface of which a viscous layer is formed. Aluminium and copper in the blend 
E20 show higher resistance than in ethanol. Again, the lowest duration of obtaining the limit degree of corrosion was for steel ( 0.5 months), while for brass -6 months.

According to the authors $[7,11]$, introducing certain corrosion inhibitors in the ethanol - gasoline blend allow to form a protective pellicle on the metal surface that prevents the output of metal ions from the surface and their interaction with oxygen or other components.
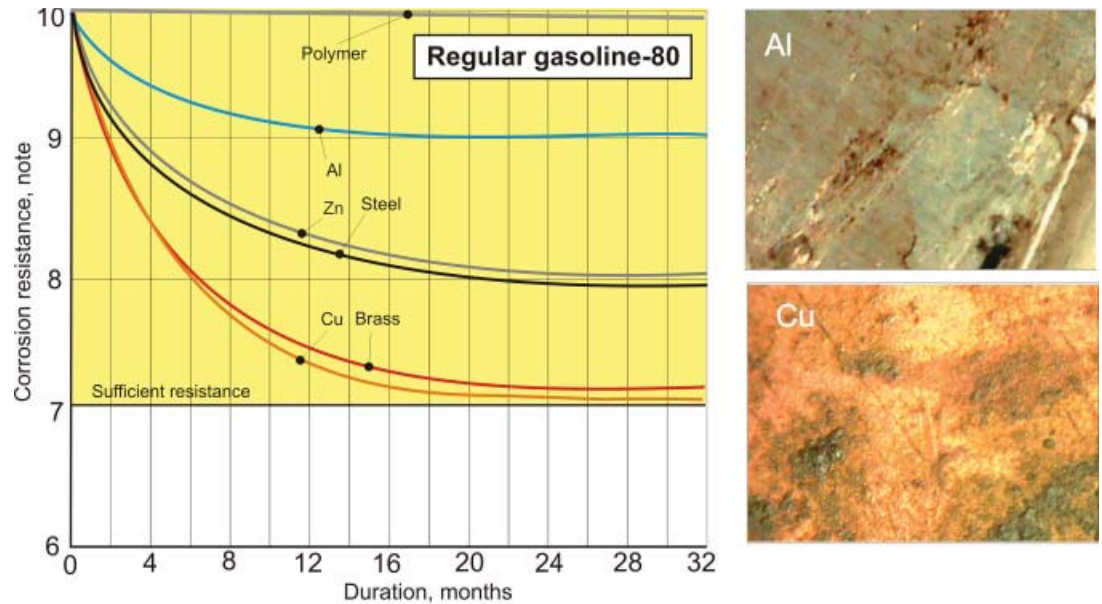

Fig.1 The Evaluation of corrosion resistance of materials in Regular gasoline- 80
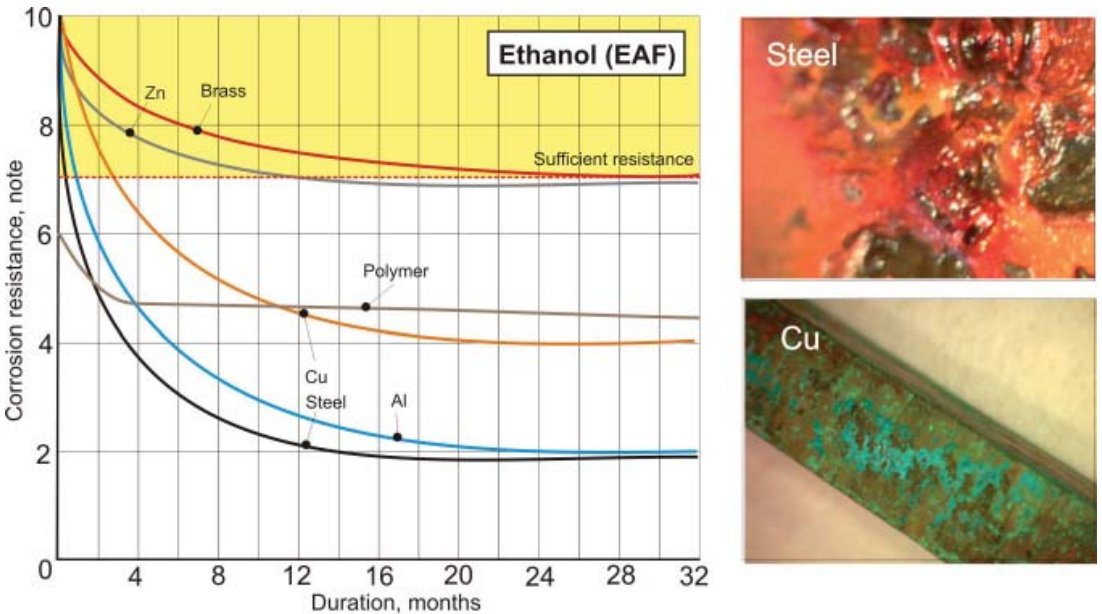

Fig. 2 The Evaluation of corrosion resistance of materials in ethanol (EAF)
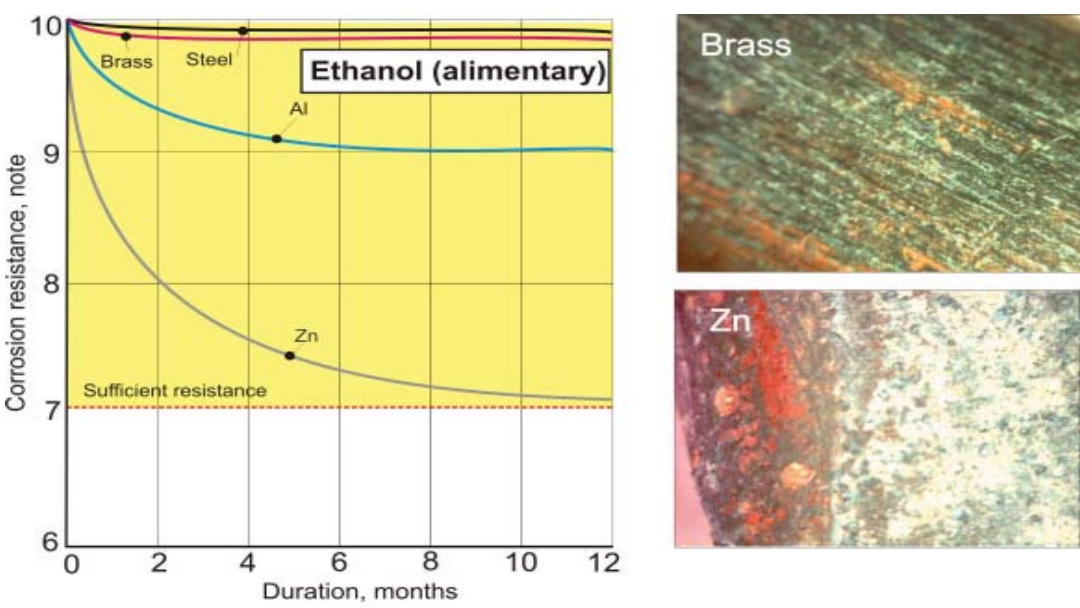

Fig.3 The Evaluation of corrosion resistance of materials in ethanol (alimentary) 

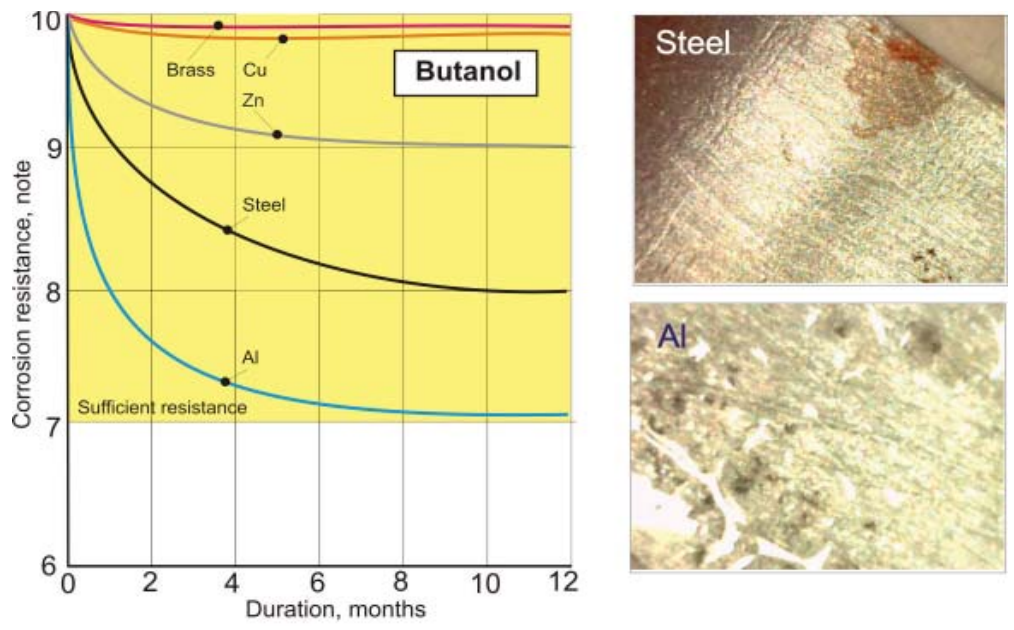

Fig.4 The Evaluation of corrosion resistance of materials in butanol

Among the studied inhibitors (triethylamine, pyridine, quinoline), only the triethylamine allowed an essential increase in corrosion resistance of all materials in the blend E20. This resistance for the zinc alloy (fig. 6, tab. 4), copper, brass and steel, is higher than the one in regular gasoline - 80. Polymer resistance is maintained at a high level. Taking into consideration the mentioned conditions, only aluminum showed a slight decrease of resistance. It is necessary to mention, that practically all materials, over a period of more than three years, maintain a good corrosive resistance level in the blend E20 - triethylamine.

The use of pyridine to reduce the corrosive activity of the blend E20 allowed insignificantly to reach the desired outcome, it was reached in zinc alloy, aluminum, copper and polymer (fig.7, tab.4). On the surfaces of these materials brittle gray or brown pellicles are formed and the liquid decanted sediments of the same color.

Quinoline has substantially increased the corrosion resistance of steel (fig. 8) forming a dark gray pellicle on the metal surface. But copper, brass and polymer decreased the resistance drastically. A smooth green deposition can be observed on metal surfaces: the membrane polymer decomposed.

In the blend butanol - B20, all studied materials showed high resistance (fig.9). The introduction of water in the blend B20 (5\% vol.) resulted in its sedimentation, practically not changing materials' corrosive resistance (tab.4). Copper and zinc alloy surfaces turned a bit darker.

In the triple blend of ethanol - butanol - gasoline E16B16 (fig.10), the corrosion resistance of steel is the same as the one in the blend butanol - gasoline B20.

The resistance of zinc alloy, aluminum, copper and brass slightly diminishes, but it is sufficient for practical use (Tab.4) and much higher than in the mixture E20 (EAF). The last phenomenon refers particularly to steel. It is necessary to mention that all studied materials lack sediments in the blend E16B16, the liquid is always transparent.

Thus, butanol in the triple blend with ethanol and gasoline has a positive influence not only on phases' stability, but also on the corrosive resistance of materials, from which the internal combustion engines are made. This fact confirms the results [6,7] obtained earlier. It is necessary to mention that high corrosive activity of ethanol is due to the strong polar group $\mathrm{OH}^{-}$. The influence of this group decreases essentially in the case of butanol $\mathrm{C}_{4} \mathrm{H}_{9} \mathrm{OH}$.
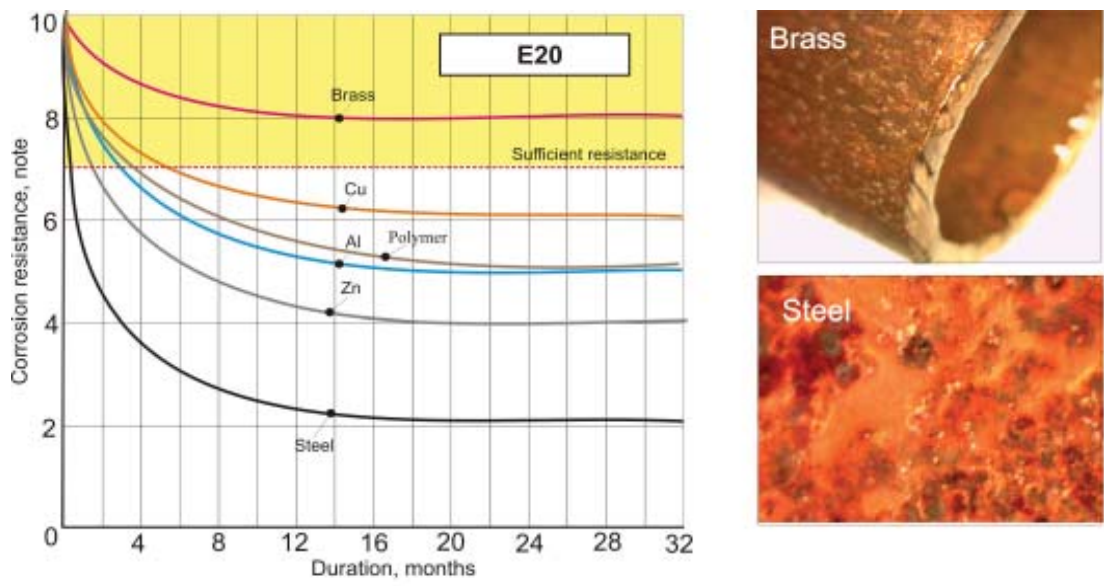

Fig.5 The Evaluation of corrosion resistance of materials in the blend E20 

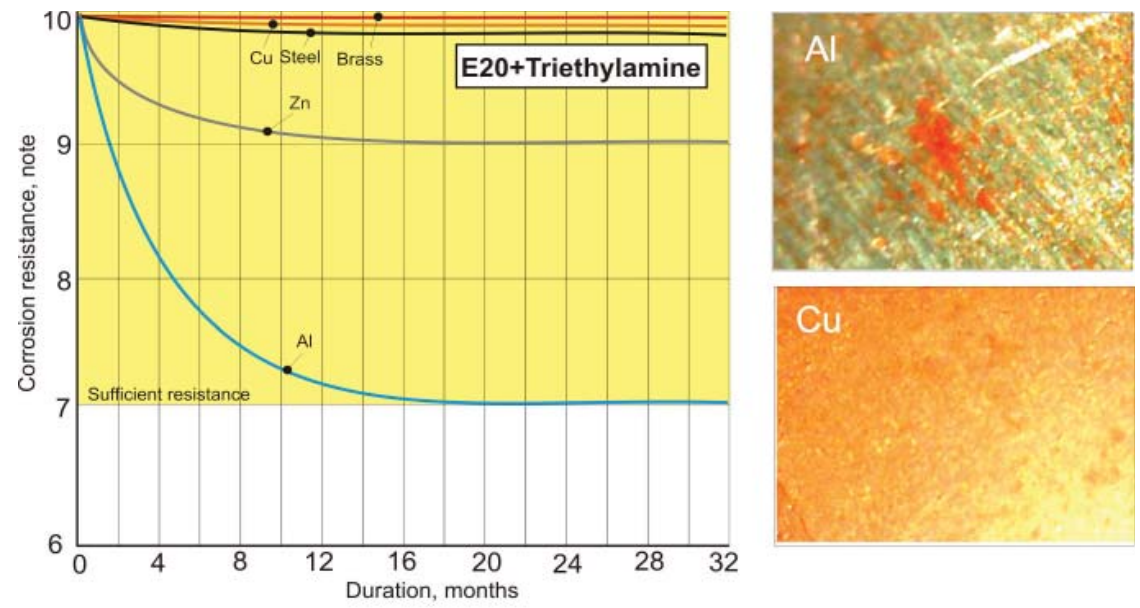

Fig.6 The Evaluation of corrosion resistance of materials in the blend E20+triethylamine
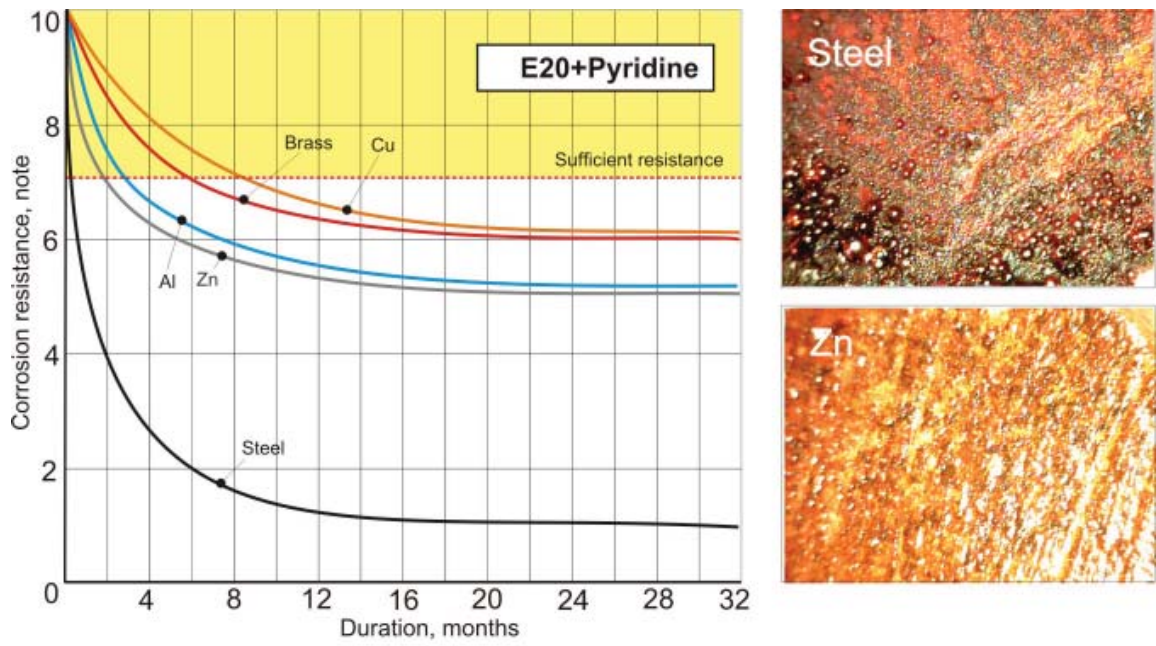

Fig.7 The Evaluation of corrosion resistance of materials in the blend E20+pyridine
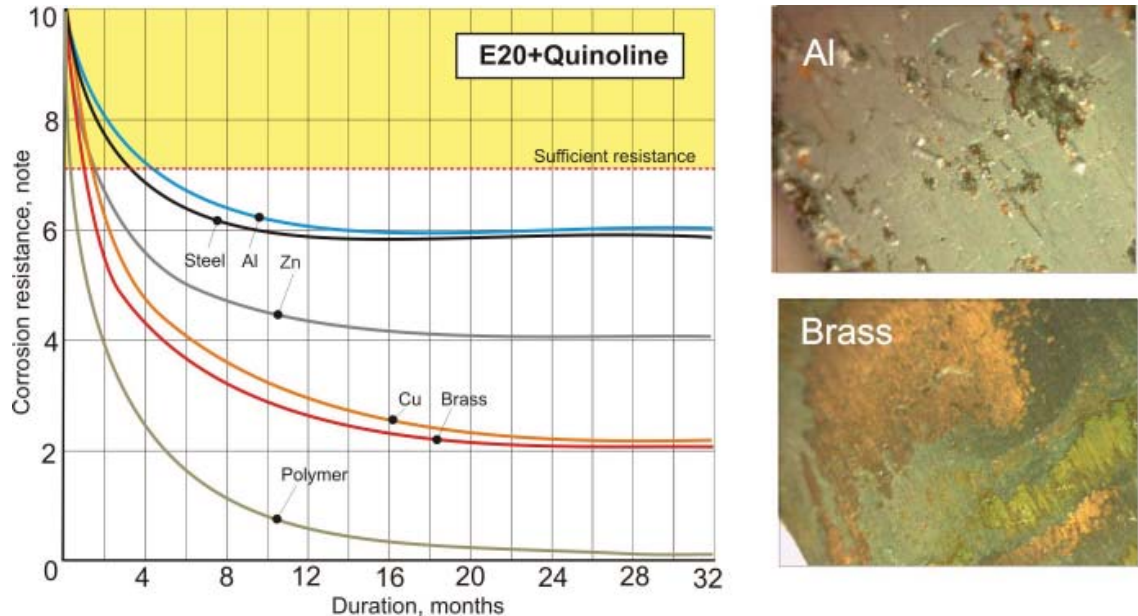

Fig8 The Evaluation of corrosion resistance of materials in the blend E20+quinoline 

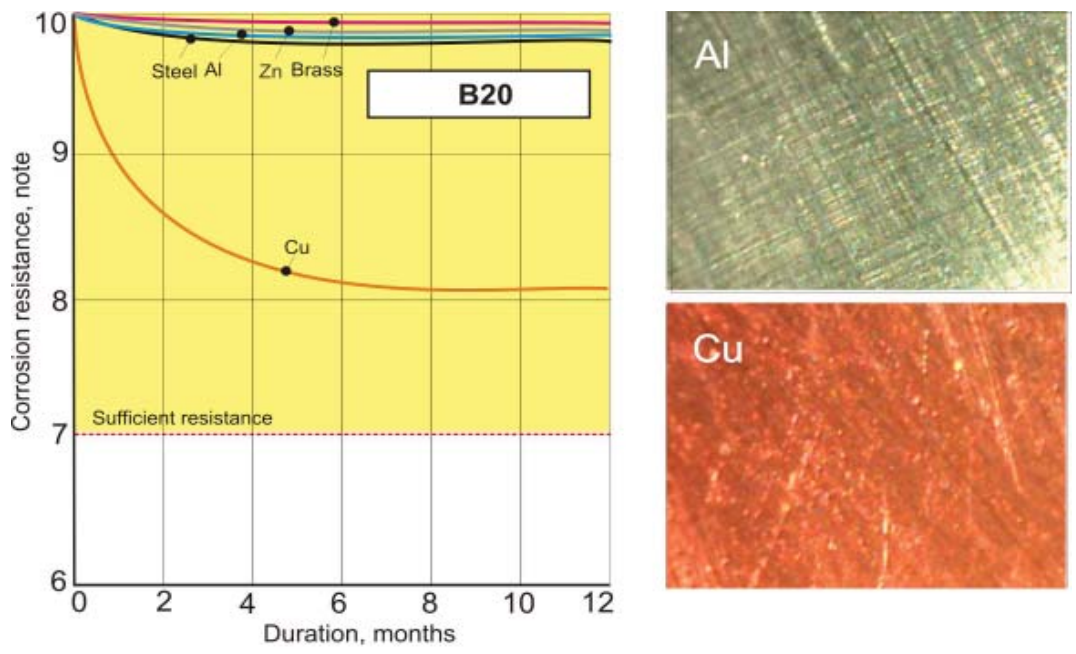

Fig.9 The Evaluation of corrosion resistance of materials in the blend B20
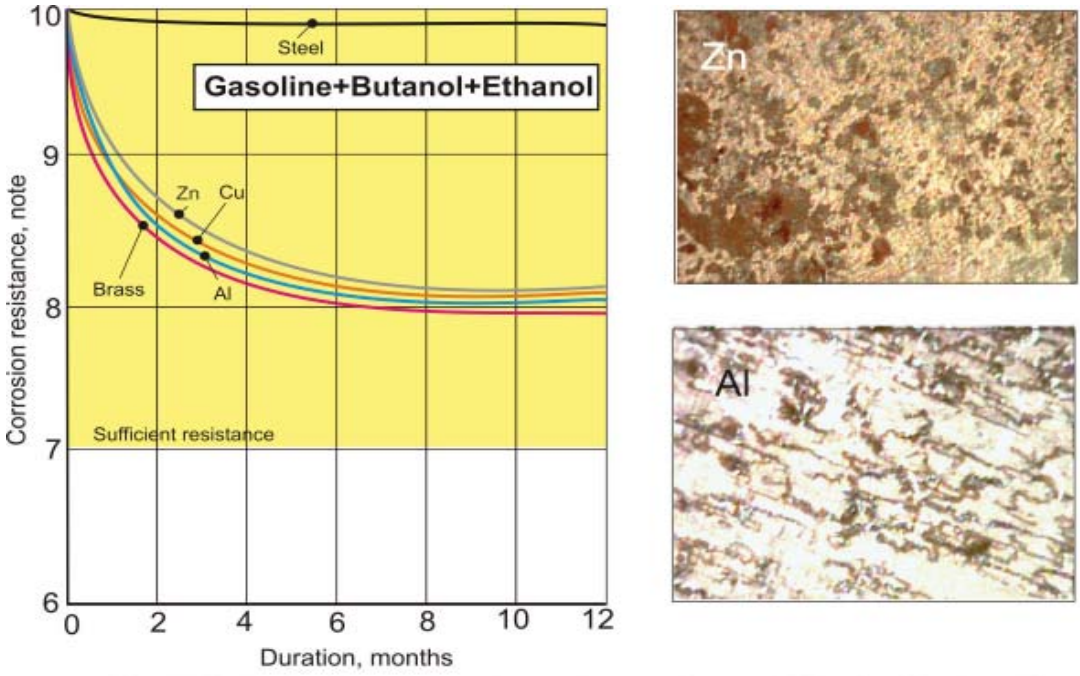

Fig.10 The Evaluation of corrosion resistance of materials in the blend gasoline+ butanol+ethanol

\section{Conclusions}

1. The studied compositions and physico-chemical properties of gasoline, butanol, food grade and technical ethanol meet regulatory requirements, which can provide sufficient corrosive resistance to materials of ICE in the mentioned liquids. The estero - aldehyde fractions concentration of ethanol have increased aldehydes, esters, organic acids, which may increase their degree of corrosive activity.

2. The study of anti-corrosion properties of different materials, performed during three years in Normal-80 gasoline, butanol, food grade ethanol showed that all materials in the engine fuel system equipment and tanks have sufficient resistance to corrosion.

3. Ethanol (ethero-aldehyde fraction) and ethanol-gasoline blend E20 diminishes the corrosion resistance of the most studied materials (except for brass). After being kept in ethanol, the aluminum, copper and steel with a low carbon content showed insufficient resistance. And in the blend E20 all materials (except brass) have insufficient resistance.

4. Among the studied inhibitors (triethylamine, pyridine, quinoline), only triethylamine allowed an essential increase of the corrosion resistance of all materials in the blend E20. This resistance for the zinc alloy, copper, brass and steel is higher than that the one in gasoline. Practically all the materials investigated during more than three years have a good anticorrosive resistance in the blend E20. The obtained results do not allow the use of pyridine and quinoline for the reduction of corrosive activity of the blend E20 on the materials from which the internal combustion engine equipment is made.

5. In the blend butanol - gasoline B20, all the studied materials showed high resistance to corrosion. The introduction 
of water in the blend B20 (5\% vol.) resulted in its sedimentation, practically not changing materials resistance to corrosion.

6. In the triple mixture of ethanol - butanol - gasoline E16B16, the anticorrosive resistance of steel is similar to the one in the blend butanol - gasoline B20. The resistance of zinc alloy, aluminum, copper and brass diminishes in the blend E16B16, but it is sufficient for practical use and is much higher than in the blend E20. In the blend E16B16, all studied materials lack sediment - the liquid is always transparent.

\section{References}

[1]. Смаль, Ф. В., Арсенов Е.Е. Перспективные топлива для автомобилей. М.: Транспорт, 1979 - 151 с.

[2]. Manea, Gh., Georgescu M. Metanolul - combustibil neconvențional. Bucureşti: Tehnică, $1992-84$ p.

[3]. Gheorghişor, M. Carburanți, lubrifianți şi materiale auto speciale. București: Paralela, 2003-324 p.

[4]. Energie din biomasă: Tehnologii şi mijloace tehnice/ Ion Hăbăşescu, Valerian Cerempei, Vasile Deleu şi alț. Chişinău: Bons Offices, 2009-368 p.

[5]. Коррозионная стойкость оборудования химических производств: Способы защиты оборудования от коррозии Под ред. Б.В. Строкана, А.М. Сухотина. - Л.: Химия, 1987 г. - 280 с.

[6]. Игнатьев, Р., Михайлова, А. Защита техники от коррозии, старения и биоповреждений: Справочник. М.: Россельхозиздат, 1987. - 346 с.

[7]. Макаров, В.В., Петрыкин, А.А., Емельянов, В.Е., и др. Спирты как добавки к бензинам. Ж. ”Автомобильная промышленность”, Nr.8, 2005.

[8]. Грандберг, И.И. Органическая химия. М.: Высшая школа, 1974. - 416 с.

[9]. Ольховская, У. Биотоплива второго поколения: за и против. The Chemical Journal, 12.2008. - p.38...42.

[10]. http://benzinavto.ru/2009/06/09/korrozya-metallov-pod-dejstviem-spirtovyh-topliv/

[11]. http://chimiegenerala.3x.ro/Capitolul3/Curs/c3_2_3.htm 